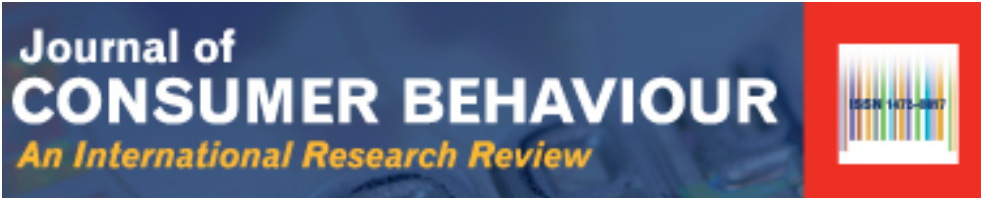

\title{
Quantifying the target market for advertisers
}

\begin{tabular}{|r|l|}
\hline Journal: & Journal of Consumer Behaviour \\
\hline Manuscript ID & JCB-21-029.R2 \\
\hline Wiley - Manuscript type: & Special Issue \\
\hline Keywords: & Advertising, Brand Growth, NBD-Dirichlet, Media, Marketing Laws \\
\hline \multicolumn{2}{|l}{} \\
\end{tabular}

SCHOLARONE ${ }^{\text {m }}$

Manuscripts 


\title{
Quantifying the target market for advertisers
}

\author{
Charles Graham* ${ }^{* 1,2}$ and Rachel Kennedy ${ }^{2,3}$ \\ ${ }^{1}$ London South Bank University Business School, London SE1 OAA, United Kingdom. \\ ${ }^{2}$ Ehrenberg-Bass Institute for Marketing Science, University of South Australia, Adelaide 5001, Australia \\ ${ }^{3}$ UniSA Business, University of South Australia, Adelaide 5001, Australia
}

\section{BIOGRAPHICAL NOTES}

Charles Graham is an associate professor in marketing at London South Bank University Business School, and an adjunct professor at the Ehrenberg-Bass Institute. Charles has extensive experience in long-term behavioural loyalty, category growth and competitive market structures. His work has been published in International Marketing Review, European Journal of Marketing, The Journal of Strategic Marketing, Journal of Retailing and Consumer Services and the Australasian Marketing Journal.

ORCID iD: https://orcid.org/0000-0001-7603-9161

Professor Kennedy is one of the founders of the Ehrenberg-Bass Institute, where she regularly advises many of the world's premier brands on evidence-based growth. Rachel has been recognised as one of "Advertising's Big Thinkers" by the Advertising Association (UK) and ranks in the top 1\% of advertising researchers. Working with Goodhardt and colleagues in the UK, gave her a leg up in her research career.

Her research can be found in the Journal of Consumer Behaviour, Journal of Advertising Research, Journal of Advertising, and Journal of Business Research, among other journals. She is also on numerous editorial boards.

ORCID iD: https://orcid.org/0000-0002-8052-6293

\author{
* Corresponding Author \\ Charles Graham \\ grahamca@1sbu.ac.uk \\ London South Bank University Business School \\ 103 Borough Road \\ London SE1 OAA
}

Acknowledgment: the authors thank Kantar WorldPanel for permission to use their data in this study. 


\title{
Quantifying the target market for advertisers
}

\begin{abstract}
Marketers who want to protect their brand's share or grow it need to know who to reach and nudge with advertising. This paper uses continuous household panel data for 55 leading, advertised brands in $12 \mathrm{cpg}$ categories to quantify their target market over different time frames and conditions (market type, brand size and dynamism). Results demonstrate that the customer base (brand penetration) must swell dramatically over time to maintain, let alone grow, market share. For stable brands, penetration typically doubles from its level in one quarter to a year, then again from one year to five years as brands continue to attract lighter buyers who underpin long run sales. Over five years, over a third of brand buyers are so light that they buy the brand just once, but such buyers are vital to sales and critical to growth. As well as quantifying the five-year target audience for brands across these conditions, we test the predictive accuracy of the NBD-Dirichlet as a benchmark. The implications for advertising and media strategy are detailed. The long-term lessons for targeting become clear - unless brands "target the market", they have adopted a counter growth strategy.
\end{abstract}

\section{Keywords}

Advertising, Target benchmark, NBD-Dirichlet, Media 
Honoring Professor Gerald Goodhardt

Gerald Goodhardt and his collaborators spent decades documenting important and fundamental behavioral patterns of interest to marketers such as: how television is viewed (Goodhardt, 1966, Goodhardt et al., 1975), how buyers buy, and how brands compete and grow (e.g. Goodhardt et al., 1984, Ehrenberg et al., 1990). Their scientific approach, and the research it continues to inspire, substantially advanced evidence-based marketing knowledge. Yet that knowledge is still not well enough known or widely enough adopted - a point Goodhardt and Ehrenberg were already making over 50 years ago (Ehrenberg and Goodhardt, 1968). Nevertheless, it is gaining global traction and the journey continues because the fundamental laws raise questions in many areas of accepted marketing theory and established practice. One such area relates to advertising and media strategy. Gerald was already aware of the implications from his time as Research Director at Young \& Rubicam Ltd (1958-65), a period when commercials were first hitting television sets across the UK, through to when he was teaching and researching advertising (e.g. Kennedy et al., 2008). We honor Gerald here by providing fresh evidence, a further extension of his most useful marketing model, the NBD-Dirichlet, and new insights from that knowledge for advertising and media practitioners. Thank you, Gerald.

\section{INTRODUCTION}

Although marketers are under pressure to demonstrate the long-run impact of their activations (Lodish and Mela, 2007, Webster and Lusch, 2013), many remain focused on daily, weekly, quarterly or annual results (at best), since that is largely how they are judged and rewarded. The "vast ocean of measurable data" further encourages 
optimization for short-term sales lift, through targeting the switching or loyalty of heavier buyers (Fulgoni, 2018). Advances in data science and technologies that promise to deliver "tailored ads to the right buyer at the right time" also embed shortterm targeting as a norm.

Central to this focus is the belief that since a relatively small number of customers are responsible for the greatest share of revenue, they should receive the largest proportion of marketing attention (Rodd, 1996, McCarthy and Winer, 2019). Targeting in this way is seen to be an efficient and effective way to allocate scarce resources. Targeting the heaviest buyers with advertising is thought to deliver higher profits because it allows management to eliminate "wasted" advertising to consumers whose preferences do not match the product's attributes (Iyer et al., 2005).

By contrast, managing brands for the longer term (for example in a five-year business planning cycle), may seem a long shot, impossible (McDonald, 1996) or even irrelevant, with some assuming it only leads to wastage and inefficiency. Understanding the effects of marketing over longer time periods is nevertheless attracting growing research attention (e.g. Leeflang et al., 2009, Ataman et al., 2010, Binet and Field, 2013, Bronnenberg et al., 2012), and there is emerging evidence of long-term outcomes from advertising (Connell et al., 2014, Lodish et al., 1995).

Despite the enthusiasm for tightly targeted campaigns, broad reach rather than targeted loyalty campaigns have been identified as more effective for top-line growth (Binet and Field, 2017). Underpinning this, it has been documented that the purchasing of heavy buyer households is not stable over time (Romaniuk and Wight, 2015) and that rather than an emphasis on heavy buyers, light buyers are critical to manufacturer-brand sales maintenance and growth ( Romaniuk et al., 2014). There is 
also a growing appreciation that the most loyal $20 \%$ of buyers may be less valuable than expected (Sharp et al., 2019, Anesbury et al., 2020, McCarthy and Winer, 2019). For large cpg brands, this suggests that ongoing investment is needed to attract or nudge millions of new and occasional consumers towards the brand, in addition to reassuring the fewer regular buyers (Barnard and Ehrenberg, 1997; Dawes et al., 2021).

Importantly for this paper, targeting a segment is contrary to the NBD-Dirichlet theory established by Goodhardt and colleagues (1984) which has now been supported by decades of evidence. The evidence and the model confirm that large and small brands depend on both heavy and light buyers, with the distribution of buying heterogeneity predictable between competing brands.

Given such competing standpoints, it seems apt to quantify exactly who brands should be targeting and reaching, over what time periods, with their advertising and other brand activations (e.g., promotions or sampling campaigns), to reconcile the different perspectives. Calls to "target the market" are consistent with the brand growth evidence but are a somewhat unspecific instruction for many media planners and creatives. In practice, broad reach is expensive, and there is often a lack of clarity of the limits to the market. Thus, this research systematically documents the target audience for varied leading, advertised brands across a range of conditions and different time periods (one year and five years) to fill this gap.

In the next section, we further discuss and contrast the issues around targeting and brand growth. We overview the NBD-Dirichlet, a robust model which describes known regularities and norms of repeat buying. We then systematically compare its projections to the observed long-term buyer base for a broad range of cpg (consumer 
packaged goods) categories and brands as a test of its usefulness as a benchmark for targeting decisions. We describe our data and method before presenting the findings and discussing the practical implications for advertising and media principles for growth.

\section{LITERATURE REVIEW}

\section{Who brands need to reach and target for growth}

Evidence from longitudinal single-source studies (tracking ad exposure and buying behavior) demonstrates that advertising for established cpg brands nudges the propensities of those who are exposed, to buy the brands they see advertised (Jones, 2006, Taylor et al., 2013). This implies that a broad reach strategy is logical for brands seeking sales and particularly growth. One recent single source study from a single chocolate brand suggests that targeting heavy brand users with advertising yields no advantage and that TV campaigns are more effective for lighter brand users (Assael et al., 2021). This fits with the idea that not all buyers (or potential buyers) are equal (Hallberg, 1995, Rodd, 1996). Clearly, there is variation in how much individual buyers spend, how often they buy and how much more they could buy (e.g., what share of their category requirements they could give to a brand), but it is vital to separate the value of individuals from the broader picture of what the brand needs to do in total e.g., to grow.

As well as heterogeneity in buying, people are expected to vary in how much advertising they are exposed to and how responsive they are to it. Many factors can drive this variation, including life stage, disposable income levels, and timing, such 
that buyers currently in-market (e.g., identified via online searches) will have a higher propensity to notice or respond to relevant ads than buyers with no current category need. Buyers in-market may well be worthy of special targeting to nudge or activate. However, such activations are expected to work best on buyers who already have established memory structures for the brand, implying longer term reach, and brand building may still also matter.

Strategies (e.g. micro targeting to mass reach) need to be considered from short- and longer-term perspectives, such as reaching daily sales targets to laying the foundation for longer-term growth. Critically, Rodd (1996) identified issues with those who ruthlessly exclude light (his low-value supporters in a charity setting) or dormant buyers and acknowledges the importance of managing "lapsed" customers for longerterm performance. Targeted campaigns to a sub-set of "priority" buyers (e.g. those who bought in the last period or loyal buyers identified from a loyalty program) can nudge them in the short term. Typically, such targets appear to be more responsive than a broader audience (and hence seem to deliver a better return), but many of these buyers would have bought anyway. Activities restricted to these "priority" subsets of buyers will naturally skew to more heavy buyers, yet brands - especially those with growth objectives - need to maintain broader reach across time. However, how broadly brands should target is often unresolved.

In terms of all buyers not being equal, there have long been attempts to quantify the most valuable $20 \%$ of customers at brand and category levels, for example, with the Pareto Ratio or law (e.g. Sanders, 1987, Rodd, 1996, Anesbury et al., 2020, McCarthy and Winer, 2019). Goodhardt was known for his 20:30:50 Law to indicate the heaviest $20 \%$ of buyers likely contribute just $50 \%$ of total purchases, the middle $30 \%$ 
account for $30 \%$ of purchases and the lightest $50 \%$ of buyers account for $20 \%$ of purchases. So 20:30:50 buyers accounts for 50:30:20 purchases (Sharp, 2010, p.46). If a brand receives $80+\%$ of its sales from $20 \%$ of buyers, a focus on those buyers would be critical. But where half of a brand's sales come from a broader audience, marketers need to give them further consideration in media and advertising planning. That is, where pareto ratios are less concentrated, it is not as advantageous to take a surgical approach to customer acquisition because the customers that are eventually acquired will be of comparable financial value anyway (McCarthy and Winer, 2019).

There are, however issues with the pareto share as a benchmark for communications planning. For example, Rodd (1996) acknowledged that pareto is static, takes no account of recency of transactions, is essentially retrospective and not a perfect forecasting method. He questioned if the ratio is consistent over several years. Behavioural stability is one of a number of important targeting assumptions discussed by Anesbury et al (2020) where heavy buyers need to continue to be heavy over time if marketing campaigns are to deliver ROI in the long run. Pareto ratios are also known to vary across conditions, including between subscription and non-subscription brands (McCarthy \& Winer, 2019) and category buying rates (Schmittlein et al,1993). Given these factors, there is scope for improved benchmarking of who to target. This requires further systematic documentation of how audience buying changes over time and other conditions. Hence, we now look to the robust knowledge, and known constraints of buying behavior and brand growth, for insights to help quantify audiences and identify conditions where behaviour is likely to vary. We then consider the NBD-Dirichlet, which accounts for many known patterns of repeat-buying in the 
medium term, as a potential benchmark for expected targets in the long-run and under other relevant conditions.

\section{Normal patterns of repeat buying in quarters or years}

There are clear empirical patterns that describe how brands compete and grow (Sharp, 2010, Sharp et al., 2012). Pioneers in documenting these, Goodhardt, Ehrenberg and their colleagues identified a number of robust laws from extensive pattern spotting in data covering weeks, quarters and later occasionally over a year or two. Importantly, they also established how to model them (e.g. with the NBD, then NBD-Dirichlet) acknowledging important assumptions (e.g., Ehrenberg (1988); Uncles (1995), and Sharp (2010)) e.g. near-stationary buying). Drawing on this extensive domain, it is known that brand sales and growth in successive equal periods are the product of two key behavioral factors - the penetration of households that buy at least once (denoted $b$ ), and the average rate at which those households buy (denoted $w$ ), such that $b w=$ brand sales per hundred households. This sales equation (Uncles and Lee, 2006, Singh et al., 2004) is a useful metric of relative brand performance in any time frame and a key focus in this paper. It has important implications for advertising strategists and media planners, capturing in its ratio the balance between "loyalty" and "reach" (see e.g. Clemmow, 2012, Ehrenberg et al., 2004). Although the sales equation suggests that penetration and rate of buying might be independent, they are not, instead being constrained by Double Jeopardy, the law like-relationship in which small brands are predictably hit twice. Small brands have fewer buyers than larger rivals, and their buyers are systematically slightly less loyal on average (Ehrenberg et al 1990; Graham et al., 2017). 
Further generalized (but surprising) patterns are that markets are typically stationary and unsegmented, and that behavioural loyalty metrics (e.g., repeat purchase, SCR, average purchase frequency) vary predictably in line with penetration as Double Jeopardy or the more comprehensive NBD-Dirichlet describe. The observation that heavy and light category buyers are predictably distributed over the customer bases of all competing brands is fundamental to these known patterns/models of brand competition and growth. It supports the proposal that building the number who buy a brand at all must underpin evidence-based growth strategy. It seems plausible then, that the NBD-Dirichlet would provide robust benchmarks for who brands need to target while accounting for known differences across categories (e.g., market type such as repertoire to subscription) and brands (e.g., brand size).

An additional pattern is that average brand purchase frequencies are low compared to category buying rates (Ehrenberg et al., 2004). The evidence is that most buyers buy more than one brand in a category (repertoire buying is the norm), with few buyers being $100 \%$ loyal to a single brand. Their split-loyalties are a contributor to repeatpurchase rates being low from quarter to quarter. Thus, as long as a category remains in equilibrium (Graham, 2009), brand penetrations remainconstant in successive quarters, although with a different mix of repeating, returning or new buyers purchasing in each period. The longer the time period analyzed, the more customers a stable or growing brand attracts, and so the quarterly or even the annual buyers cannot be taken to represent the brand's long-run customer base. Documenting who buys categories and brands over the long term (e.g. over five years) and across known conditions that vary is particularly important now, given the very substantial changes occurring in the media world. 


\section{The new media world}

In recent years media planning has rapidly evolved. New technologies enable brands to behaviorally target and personalize communications in real-time on smart / connected devices, thanks to programmatic scheduling, artificial intelligence and more. But in this world, many practitioners lose sight of, and contact with, their nonbuyers, focusing instead on existing customers or those with a high propensity to buy. These "intent marketing" tactics have been challenged (e.g. Fulgoni, 2018, Montague, 2019) for losing sight of the broader effort needed to keep the "funnel full". While most marketers agree that reaching new buyers is useful for growth, far more contentious is the role or priority to be placed on reaching the many non- and/or super-light buyers. Many buyers may not know or care much for the brand (or perhaps even category), or at least, may not identify their intent to buy in ways that allow them to be identified and reached.

The contention arises because it is unclear how broad any target market should be, and how this should change for brands of different sizes and across varied conditions. Like for brands that want to maintain share, versus those that desire growth.

Measured in a single year, categories differ greatly in penetration, purchase frequency and in other respects. But there is a lack of knowledge as to how category and brand buyers cumulate over the longer term, how their purchasing is distributed across available choices, and specifically, what this implies for advertising planning and media scheduling. To determine what advertising can and has to do in the long-run, marketers need robust evidence-based behavioral benchmarks of who to target and how those target audiences evolve over time and across conditions. Hence our aim is to document how broad the target market becomes for brands across categories and 
how category and brand buying varies systematically under key conditions. We therefore ask specifically:

RQ1 How does cumulative category buying vary over time (e.g. between one and five years)?

RQ2 How does cumulative brand buying vary over time and conditions?

RQ2a How does cumulative brand buying vary by market type? RQ2b How does cumulative brand buying vary by brand share?

And, leading to our final Research Question, we look to benchmark the answers to these questions, to quantify reliably who to target over time.

\section{The NBD-Dirichlet: An evidence-based benchmark of who to target}

In the short term, stochastic models that ignore the many determinants of choice are remarkably accurate in their aggregate predictions of repeat-buying. One of the most highly generalized (Sharp et al., 2012) is the NBD-Dirichlet (Goodhardt et al., 1984), Gerald Goodhardt's major contribution to marketing science. Since its publication, an intense process of scientific replication and testing led Sharp to describe it as "one of marketing's true theories" (Sharp, 2010) because it captures repeat purchase behaviour under many varying conditions of category, country, and time. The model has five assumptions:

i. That individual category purchasing follows a Poisson process.

ii. That the purchase rates of different buyers follow a Gamma distribution.

iii. That the choices each buyer makes from available brands follow a multinomial distribution. 
iv. That these choice probabilities follow a Dirichlet distribution over buyers.

v. That purchase incidence (i \& ii) and brand choice (iii and iv) are independent.

The Dirichlet combines these assumptions in two probability density functions, the negative binomial distribution (NBD) describing purchase incidence, and the Dirichlet multinomial distribution (DMD) for brand choice, to model simultaneously the numbers of purchases for each brand in a category over a fixed period.

No marketing mix variables such as media spend are required as inputs. The model is usually calibrated using metrics available in panel data - brand penetration $(b)$ average purchase frequency $(w)$ in a given period $(t)$, plus the associated category measures. It provides a parsimonious method to estimate the expected market to target for different sized brands across diverse category types and conditions.

The model assumes that both category and brand penetration accumulate with time. Because any category contains many light buyers, it takes time for everyone who will eventually buy, to buy. Therefore, the size of any stationary market is bigger in six months than it is in a quarter and bigger in a year than it is in six months. The model also assumes that brands share buyers; that every buyer has some probability of buying every brand, no matter how low. The distribution of those probabilities predicts the rate of growth in brand penetrations and the increases in average purchase frequencies in longer time frames. Just as time is expected to increase the number of repeat brand purchases made by heavier buyers, equally it must also introduce many more light brand purchasers. 
Finally, in stationary markets, although category purchases accumulate over time, brands must hold the same share of total sales (e.g., in one or five years). The sales of any brand (or category) in any period then depend only on the proportion of the population who bought at all, and how often they bought on average (the sales equation). The NBD-Dirichlet describes the Double Jeopardy (DJ) characteristic of this equation (Ehrenberg et al, 1990) in a given period; that the difference between competitive performance is in the number of buyers a brand has (big differences), rather than in their loyalty (which hardly varies, in the short run).

The NBD-Dirichlet is specified for stationary markets, but it benchmarks sources of deviations from strict stationarity in empirical data. Many studies have identified that growth (or decline) in brand performance is closely associated with an increase (decrease) in buyer numbers between successive equal length periods. They also show that the purchase rates of the buyers in both periods are distributed predictably between heavy and light, such that average purchase frequency changes little (Dawes, 2016, Nenycz-Thiel et al., 2018). Hence, existing advice for broad advertising reach, to target the market to nudge the additional buyers, is based on a robust evidencebased theory.

An important feature of this model is that a successful fitting to one period can be projected to multiples of that period to predict the cumulative metrics for stationary brand and category performance. The Dirichlet has been widely adopted across industry to benchmark and evaluate competitive brand performance (Sharp et al, 2012). Typically, this is done using quarterly or annual data. Testing the model's 
accuracy over cumulative long-run buying, including dynamic brands, is a novel application. If the model gives a reasonable fit across five years, it would predict and explain cumulative category and brand performance by linking the short and long-run. With robust benchmarks for who buys over time, different advertising and media strategies could be evaluated against expected performance and appropriate media briefs and objectives written. Therefore, our final Research Question aims to validate the NBD-Dirichlet as a benchmarking tool for long-run targeting decisions and asks:

\section{RQ3 Are NBD-Dirichlet benchmarks of cumulative buying robust for longer term advertising and media planning?}

\section{DATA AND METHOD}

To document who buys categories and brands over an extended period to guide advertising and media strategy and validate how benchmarks hold, a five-year UK household panel dataset was filtered for continuous reporters from 2009 to 2014 . Twelve cpg categories were selected to represent a range of penetration and buying frequencies. In each category, performance metrics were extracted for the five leading advertised brands (or less if fewer were advertising). Future work should also document non-advertised and smaller brands for comparison.

In total, fifty-five leading brands were identified, accounting for the majority of the advertising investment shown in Table 1 . It shows an average annual category advertising expenditure of $£ 37$ million or just under $7 \%$ of retail sales, with about two thirds of that spend on TV. 
Insert Table 1 about here

For each category and brand, sales equation metrics, market shares, and the underlying distribution of purchase frequencies were recorded in cumulative aggregations of time to allow quantification and comparison in one and in five years. To evaluate the NBD-Dirichlet as a long-run benchmarking tool, cumulative five-year estimations were projected from annual fittings using software developed by Kearns (2002).

Our approach was to follow the work of Goodhardt and colleagues (Goodhardt et al, 1984; Ehrenberg, 1995; Kennedy et al., 2018) in seeking regularities and law-like relationships in the data. To answer our Research Questions, results were tabulated for observed $(\mathrm{O})$ and theoretical $(\mathrm{T})$ metrics across the twenty-four separate fittings. The aim was to highlight significant sameness, suggesting novel empirical generalisations that with replication could become managerial benchmarks and explanatory theory.

\section{RESULTS}

\section{(RQ1) Quantifying cumulative category buying}

In response to the first Research Question, we present in Table 2 the cumulative category buying metrics in sales order, using the sales equation. From the perspective of who brands need to target, there is an important pattern in long-run buying visible 
from this cross-category comparison. Although sales development is quite consistently linear (i.e., in these stationary categories, the sales per 100 households are five times higher in five years than annually), the number of buying households (the size of each market) increases by an average of 50\%. Ice cream, the only highly seasonal category, deviates slightly with slightly lower build in cumulative sales, but it shows the highest growth in penetration over time. Consequently, for long-run advertising and media planners, the market to target is itself a moving target.

Table 2 shows that, on average, category purchase frequency increased about three and a half times, but between categories, the consistent sales result is the product of very different rates of growth in the two sales equation measures. For example, Laundry Detergents are bought at least once by $90 \%$ of households in one year, with accumulating category sales over five years largely the product of repeat buying, not of new detergent buyers. This is expected as the annual penetration is already at (or very close to) the ceiling. But for Men's Razors the opposite is the case.

Accumulating sales are the result of a doubling in the number of category buyers, and a far slower build in repeat purchase over time.

\section{Insert Table 2 about here}

Further, markets are of widely differing sizes in one year, ranging from $90 \%$ of households (detergents) to just 15\% (nappies). While some initially smaller categories then reach about nine in ten households over five years (e.g., moisturisers, $88 \%$ ), others are naturally restricted (e.g., dog food or nappies) in this timeframe. 
It is suggested that such cross-category differences are of consequence to marketers (Fader \& Lodish 1990; Trinh \& Anesbury, 2015). What is new here is investigating these differences across cumulative buying. In repertoire markets, where all category buyers represent some opportunity to maintain or grow brand sales "target the market" has a different a meaning for restricted markets (only those with a pet or baby) compared with mass markets (detergents and biscuits). This is important background for the following brand-level analyses in response to our next Research Question.

\section{(RQ2) Quantifying cumulative brand buying under different conditions}

The original sample consisted of 55 leading advertised brands, of which 46 were stable and form the basis of the analysis. The nine dynamic brands were excluded from the analysis (five showed share increases between three and six points, and four a loss of between three and seven points).

The cumulative performance metrics of the stable brands were collated in various periods of continuous buying, ranging from one quarter to five years. While Table 3 demonstrates the analysis for a single category, the main patterns were consistent across all stable brands. It demonstrates how we quantify cumulative brand buying effects in a competitive context, starting with market share. With short term fluctuations, when viewed in time series, brand shares tend to remain persistently stable around their long run mean (Graham, 2009). In Table 3, to smooth volatility, we show performance in an average quarter and compare it with the first year in the dataset, and the cumulative results for all five years. Market shares of stable brands remain unchanged whatever the time and sales aggregations examined. 


\section{Insert Table 3 about here}

The final columns in Table 3 reflect the sales equation. Just as the annual category sales per hundred households are a fifth of their long-run total, the same is true for each of the five leading deodorant brands. Again, that regularity obscures critical differences in the development of each brand's customer base. Consider, Lynx. In one quarter, the brand was bought by fewer than ten percent of households. By the end of five years, it had reached nearly half of them, yet its brand share was unchanged. In relative terms, the smaller brands were bought by three times as many buyers in a year as a quarter, and then showed a further three-fold growth in customers between one and five years - again, just to stand still and maintain their share.

Aggregating this finding by averaging stable brand metrics in rank-share order, we found that for a typical leading brand, customer numbers double from a quarter to a year, and double again from one year to five but with no change in share in any time window. This means that half of a brand's annual customer base does not buy in the first (or in any) quarter, and half its total customers do not buy it in the first year.

Cumulative effects: brands and categories add buyers at different rates over time

To establish what it entails to "target the market" for long term brand performance, the cumulative rates at which categories and brands continue to attract "new" buyers are comparedin Figure 1. Between one and five years, brand penetration doubles but in the same period category penetration grows by only a third. Thus, much of the continuing brand penetration growth is the result of brand switching. But given that 
category growth rates vary substantially (Table 2), competition for buyers may vary over time across categories; quantifying this is the focus of Research Question 2a.

Insert Figure 1 about here

\section{RQ2a How cumulative brand buying varies by market type}

To quantify cross-category effects on cumulative brand buying, we built on earlier work (e.g. Trinh and Anesbury, 2015, Fader and Lodish, 1990) that had classified categories by their rate of penetration and purchase frequency. Taking the average annual category penetration and purchase frequency as a cut-off, we created four classes of market, then examined the development of cumulative buying in each, in one year and five years of sales, on three metrics: sales per 100 buyers; penetration; and average purchase frequency. We then derived the same average performance metrics for the sampled brands in those category classes, and included a fourth measure, the average proportion of one-time brand buyers in each period.

The cross-category classification in Figure 2 is robust to cumulative performance. This confirms its validity, and we demonstrate that buying metrics accumulate in different ways. The heaviest bought categories at the top right ("Staples" in prior studies) are over ten times the sales volume of the lowest ("Fill-Ins", bottom left). Cumulative category sales growth for Staples is almost completely the result of increasing purchase frequency (W), and this is reflected in brand buying: average penetration grows at the slowest rate but purchase frequency at the fastest. 


\section{Insert Figure 2 about here}

In the smallest category ("Fill-Ins", bottom left), the opposite is true; brand and category are still finding new buyers after five years. This is also true of low purchase frequency but high penetration categories (bottom right) where the longer category inter-purchase interval suppresses penetration growth rate. Prior literature names these products "Variety Enhancers" which now seems an inadequate definition in light of their identity (shampoo, deodorant) and cumulative development. The fourth class ("Niches", top left) is different again. Penetration growth here is limited by the large proportion of hard-core non-buyers defined by category functionality. But since purchase frequency is high for those who do buy, fast growth in repeat buying is necessary to maintain brand share.

In each category type, between one and five years, average repeat-purchase increases and the proportion of one-time brand buyers falls but with a systematic variation. In the "Staples" category, one-time buyers account for a quarter of the average brand's customers, but in "Fill ins" categories it is over half. In sum, the buying differences between market types play out dramatically in cumulative brand performance metrics.

\section{RQ2b How cumulative brand buying varies with brand share.}

To document the patterns in cumulative brand buying by brand size, we report aggregated results across the categories (Table 4). Here average brands by size are 
reported. The Average Market Leader comprises the average metrics of the 12 leading stable brands across the categories, followed by the Av. Follower Brands (the average metrics of the twelve second biggest brands), and so on.

\section{Insert Table 4 about here}

Double Jeopardy is apparent in brand performance across different time windows. However, while rates of buying are closely distributed around their mean in quarterly data, there is far wider dispersion in the longest window. At five years, with stable market shares, small brands depend far more on increasing penetration than increasing repeat buying (here "small brands" are still all established, advertised, brands ranking in the top five). For market leaders the reverse is true. To investigate this widening distribution of purchase heterogeneity further, we next examined the incidence of the lightest buying by brand size (Table 5).

\section{Insert Table 5 about here}

Table 5 quantifies the lightest buying by brand size in the same way as before. It shows that over five years, sales results for stable brands depend to a surprising extent on super-light buyers. Super-lights are those buying the brand five times or less in five years. Notably, there is a clear association with brand size. Smaller brands have a systematic higher dependence on super-light buyers; for Brands 4 and 5 they account 
for over $80 \%$ of all customers, yet importantly, contribute over half of long-run sales. Even for leading brands, super-lights account for two thirds of buyers, and one third of sales. For the average brand, $41 \%$ of the customer base bought just once in five years, with systematic variation in one time buying by brand size: but otherwise, repeat rates are quite homogeneous across the two times to five times buyer classes.

\section{RQ3 Is the NBD-Dirichlet a robust benchmark for longer term advertising and media planning?}

How many of these cumulative buying patterns are captured by the NBD-Dirichlet? To address the third Research Question, we compared observed data with annual fittings and model projections to five years of cumulative purchasing (Table 6). We aggregated the performances metrics by rank share order within each category classification, using a MAPE statistic to assess the fit on penetration, purchase frequency and one-time buyer proportions. Table 6 shows that fittings to annual sales are close. There is little surprise here; it has long been suggested that we live in an NBD-Dirichlet world (Sharp et al 2012). The projected sales per hundred values for the average brand over time are also close with little error in the accumulation. But the five-year projected fittings systematically under-predict penetration, and overpredict purchase frequency for all brands in much the same way as the NBD does for a single brand (see Dawes et al., 2020;2021). It means stable long-run brand performance depends on lighter buying (a couple of units fewer than expected in five years), by many more buyers. The differences are most pronounced in the low penetration categories, where behavioural loyalty is far lower than expected, and brands need higher penetration growth for stability. 
Therefore NBD-Dirichlet stationary benchmarks across five-years, although biased, still broadly seem robust while also providing important insights (e.g into long run cross-category buying differences). The projections quantify and emphasise how far large advertised brands maintain sales mostly through penetration cumulation. This has implications for media and advertising which are detailed next.

Insert Table 6 about here

\section{DISCUSSION \& CONCLUSION}

The main findings from this study are summarised in Table 7 before key implications and contributions are detailed.

\section{Insert Table 7 about here}

Establishing who buys over five years identifies that the main marketing challenge for brand maintenance or growth is not targeting. By design, targeting - beyond reaching category buyers - limits the reach of any advertising campaign or other activation and hence its ability to nudge vital buyers and sales. Long run brand performance depends on maintaining cumulative penetration growth. So unless mass reach is achieved, the 
expanding customer base, most of whom skew light, could be at risk of not buying the brand or not buying so soon.

However, categories do vary somewhat with systematic differences identified. Hence cumulative category buying characteristics should be considered when making advertising and media targeting objectives, as summarised in Figure 3.

\section{Insert Figure 3 about here}

\section{High Penetration, High Purchase Frequency Categories}

In these categories, it is vital that advertising nudges category buyers to buy the brand. The default expectation is for no further or very limited category growth - all buyers in year one, are likely to buy in year two, three and so on. Brand repertoire buying is the norm, with brand and category memories likely to remain strong, because high average purchase frequencies mean memory structures are frequently refreshed.

\section{High penetration, Low Purchase Frequency Categories}

Advertising in these categories is needed to nudge buyers back to the category as well as the brand. Annual category penetration is lower in comparison to High Penetration /High Purchase Frequency categories but reaches $80 \%$ of buyers after five years. One third of eventual buyers are not present in Year One, but category penetration grows over time largely because Purchase Frequency is lower - there are relatively longer inter purchase intervals. The expectation is that brand memories are likely to be more fragile, and brands less familiar, so consistency of branding and nudging will be vital. 


\section{Low penetration, High Purchase Frequency Categories}

In these markets, there is a limit to the total category size: for example, those who do not have a baby have no need for baby food. For those in-market, Purchase Frequency is high, so reaching and nudging these people, where possible, is likely to be important, especially where there are scale opportunities to reach them.

Over time there is still some category accumulation which marketers should consider. Establishing links to the category and being easy to notice for those who do come into the market is likely to be important. In these categories, there is probably the most opportunity for online activations that help the brand get noticed and considered (e.g., relevant information or special offers to those searching in-market). We documented here that the longer-term market includes one third of buyers who were not present in Year One, suggesting that leading brands in these categories need to sell and build associations for both the category and their brand.

\section{Low penetration, Low Purchase Frequency Categories}

In these categories there is a high rate of category growth over time because the products are broadly appealing but purchased infrequently. Relative to other categories, sales remain low, although brand penetration still grows three-fold over five years. There is an important role for advertising to nudge the category as well as the brand, although this may be a bumpy ride. Although Trinh and Anesbury (2015) identify an association between brand share growth and low category penetration, Dunn et al (2020) find that the smaller the category penetration the higher its volatility. Advertising strategy here might focus on achieving persistent rather volatile share gains, and, for leading brands this might grow and stabilise the category itself. 
Overall, these results provide important insights into who brands need to target over a five-year planning cycle, with identification of key conditions that matter. We also provided a validation of the NBD-Dirichlet as a longer-term targeting benchmark. We now discuss the theoretical implications of these findings and contextualise their importance for advertising and media planning.

\section{Model and theoretical implications}

For academics, and those interested in the technical details of the model fit, this study suggests the projected NBD-Dirichlet outputs provide a useful benchmark, although not a close fit to longer-term buying, for who brands should be reaching and nudging with advertising. The fittings reveal that a known bias in estimating the importance of one-time buyers, unimportant in the short run, becomes more pronounced in longerterm buying. More work will be required if a closer fit is needed.

The NBD-Dirichlet assumptions are of strict stationarity, so the surprise in the fiveyear fittings is not that model estimations are slightly biased, but that even over five years the predictions are as close as they are. They imply that in the long-run, marketing efforts serve largely to maintain existing propensities, especially those that are so light that they manifest only in super-light buying. The extent of this has rarely been observed even though it has always been present in the NBD-Dirichlet parameters. The bias is systematic in its reflection of the observed Double Jeopardy characteristic, which means that smaller brands (and here that still means leading advertised brands) must attract more buyers at lower loyalty than bigger competitors. Smaller brands depend on penetration increases to the extent that over $80 \%$ of their buyers bought just five times or even less over five years. In theory, over the long run 
smaller brands could grow by retaining buyers; in practice, these results reveal that none seem to, and not even to the extent projected by the model.

In Goodhardt et al (1984), a discussion of the model parameters K and S suggests that they might be useful in categorising category buying differences. This was also a subject of discussion in Sharp et al (2012). Given the advertising implications of different rates of cumulative penetration growth, further work is now needed to link these ideas.

While there may be scope to improve the NBD-Dirichlet as a targeting benchmark, these fittings reinforce the importance of penetration and hence reach, raising a warning flag about segmentation and targeting especially over the longer term. Implications are expanded in the fundamentals for marketers below.

\section{Practical implications for marketers}

For practitioners, the evidence supports much that is already known about how brands grow from the short to the medium term. However, this research provides additional empirical quantification of who needs to be targeted and nudged for long-run brand maintenance or growth. While the evidence provided was from large, stable and dynamic cpg brands, given the close fit of the model which is known to hold across diverse conditions, the lessons are expected to be similar for a broader range of brands including those in services and durables.

Many marketers will struggle to access long-term continuous data. Hence, we recommend the use of quarterly and/or annual data to describe markets. These results then support the use of the NBD-Dirichlet for scenario planning and to quantify the 
broader market brands need to reach over longer time periods, especially if they have growth targets.

Considering the generalised findings, we propose recommendations for media scheduling, creative planning and execution, for those concerned with long-run brand performance and maximising return on marketing investments. While appreciating that the differences across conditions already discussed are important, the top line recommendations are to:

\section{Target your market (category)}

The rate of penetration growth demonstrated in Figure 1 (and predicted by the model) shows that successful brands nudge new (or very light) buyers to buy them, quarter after quarter, year after year, typically in very large numbers to support market share. There is some variation by market types as detailed, that marketers need to cognisant of but the default is that buyers must be acquired or nudged to re-buy, to drive growth. Brands therefore need advertising reach.

Brand growth mostly occurs through penetration increases, plus small increases in purchase frequency, in successive periods. Decline occurs when brands fail to attract buyers, far more than by failing to retain them (Dawes, 2016, Riebe et al., 2014). Our observations of cumulative longer-term data provide compelling evidence for advertisers as to why it remains crucial to target the whole market - category buyers not just the brand's heaviest buyers (Kennedy and Hartnett, 2018). Reach should be a key metric for all media schedules because the long-run customer base must be so 
much larger than indicated by a single year's sales. This research provides some benchmarks for how much larger.

\section{Appreciate that targeting is counter scale}

Our evidence puts the emphasis on short-term behavioural targeting and optimisation in perspective. Although delivering the right message to the right prospect at the right time is intuitively appealing, it is counter growth because by design, it is limited only to high propensity buyers who can be identified. The NBD-Dirichlet assumptions mean that competing brands share heavy and light category buyers over a year but as we show in Figure 2, they will share substantially more of them over five years. Successful brands must target the whole market to maintain the scale of future sales from their many light buyers. Like salt in cooking, a little targeting can be useful but too much should be avoided for those following a maintenance or growth strategy. Smart targeting does have a role, such as helping to build memories with those likely entering the market. This is particularly useful in Low penetration / High purchase frequency categories (e.g. those having a baby or getting a pet).

\section{Avoid the lure of the heavy buyers}

If marketers are trying to maximise returns by focusing exclusively or heavily on heavy buyers, at the expense of light buyers, they will struggle to maintain brand sales. Such a strategy is unlikely to deliver share growth. Table 2 and particularly 3 show it is not possible to change the shape of the buyer distribution (i.e., grow heavy buying alone). The evidence for Double Jeopardy in cumulative analysis means the priority for all brands is to continue building the numbers buying the brand at all. Penetration is the metric that matters, not a focus on heavy buying alone. 
Measurable behavioural effects may seem to confirm that online activations are efficient, but above the line advertising (e.g., TV, and other online mass video) still delivers the necessary mass reach at low CPMs. It provides access to more category buyers, many of whom have not bought the brand yet, or recently but could in the future. To make the point with an example from our high growth, high purchase frequency category, Persil is bought by 1.4 million UK households in any quarter. But to maintain its market share over five years, it must find its way into the washing machines of 17 million households, sometimes, over those twenty quarters. Only mass advertising effectively delivers the kind of reach needed to achieve this.

\section{Creative should work at scale; it should look like the brand}

There are also advertising-creative implications in targeting the market. For creative strategy and execution, our findings are consistent with advice that marketers should worry less about measures of engagement or brand love and worry far more about advertising that grabs attention, and that refreshes and build relevant memories at scale. Much brand advertising sells, but not all campaigns work to drive sales (Jones, 1995, Bellman et al., 2017). Our research emphasises reach, but it also suggests that the creative must broadly appeal to a wide market, where repertoire buying is normal, and many buyers are very light buyers. Therefore, advertising should be clearly branded, both directly and by using distinctive brand assets (Romaniuk, 2018), because light buyers matter so much to total sales outcomes.

This suggests that consistency over the long-term matters. Light buyers have less developed memory structures for any brand (Kennedy et al., 2017). They may buy it only once or twice in five years, so it is critical to ensure for these buyers that the brand is consistent in how it presents itself, making it easier to notice, to recognise its 
brand activations like advertising, and to bring it to mind in cluttered store or online environments.

Creative publicity for brands still enables marketers to have fun and keep their messaging fresh (Ehrenberg et al., 2002) but our findings highlight why new positioning or new messages can be problematic. The original messaging is fragile enough for most of the market who do not yet have the brand in their regular repertoire. The role of advertising is to maintain associations between brand knowledge and the brand's distinctive assets (Romaniuk, 2018) for as many category buyers as possible. "Refreshing" those distinctive assets risks disconnecting existing brand-memory structures from on-pack cues (Romaniuk, 2018) for large numbers of consumers, especially the many super-lights who have not bought it for a year or two.

Advertising measures that are likely to matter include correct brand attribution or linkage, where single source data is not available to determine sales effectiveness at scale. Having a clear understanding of the brand's distinctive assets is also fundamental to producing great copy that looks like the brand to category users. Ensuring viewers respond at scale should also be tested; do they laugh where they should, and continue to give the advertising their attention (Bellman et al., 2019, Bellman et al., 2017).

\section{Copy should refresh relevant memories}

These results highlight that by far the biggest communications challenge is to reach and nudge those who may not yet know the brand, or at least not well, particularly in certain category types. As Ehrenberg (1974) pointed out, sequential persuasion sales models "fail to explain the known facts" (with more evidence provided here). Although most brands remain near-stationary they maintain or build their share 
through a complex flow of new and light buyers, as Goodhardt and Ehrenberg saw in short term data, a process that we now confirm continues at a far larger scale over years.

In this context, the empirical generalisation that brand advertising is twice as likely to be remembered by users than non-users (Romaniuk and Wight, 2009, Vaughan et al., 2016) does not imply advertising is ineffective with non-users. Rather, it is consistent with them having fewer memory associations for brands they do not buy (or do not buy often). Recent eye tracking research suggests that light and non-buyers pay attention to ads for brands they do not buy (Simmonds et al., 2020). This means that there is the possibility of building and re-enforcing relevant memory structures across the market through advertising, to increase the likelihood of these brands being considered by more light buyers when they have a relevant need.

\section{Nudge lights and others when they are in the market}

This evidence also supports the recommendation for continuous media schedules (Gijsenberg and Nijs, 2019), which maximise recency and continuity, rather than schedules which burst or flight and then go dark for extended periods. The prevalence of super-light buying (category and brand) means that it is easy for brands to be forgotten, particularly when so many of their customers are buying other brands in the meantime (Stocchi et al., 2016). A long interpurchase interval is common to all brands for most of their buyers. It does not mean that individual households are unsatisfied (or that the customer bucket is leaking) - they are more likely to be simply uninterested - most detergents, coffees and shampoos are about the same anyhow. So, as well as measuring reach, recency and continuity are useful media metrics for those interested in brand maintenance and growth. 


\section{Limitations and further research}

Analysis and modelling of long-run continuous panel data is a new research domain, and the study has some limitations. First, it has not attempted to align in-market targeting with buying data but instead quantifies the endpoint of who needs to be reached. Further research incorporating ad exposure in relation to long-term buying patterns is called for.

Second, the data here are from a UK panel, and the analysis was conducted in a sample of continuous reporters for large, advertised brands. Further research is required in bigger samples, different countries, across more categories and more diverse brands. Including smaller brands and those that have not advertised including private label brands. A wider range of brand metrics from the NBD-Dirichlet may also be worthy of more systematic documentation.

Third, emerging streams of advertising research in eye-tracking and neuro-response are providing promising results in explaining brand and advertising responses of nonand light buyers. Further work here is critical to advance advertising effectiveness among these groups. 


\section{REFERENCES}

ANESBURY, Z. W., TALBOT, D., DAY, C. A., BOGOMOLOV, T. \& BOGOMOLOVA, S. 2020. The fallacy of the heavy buyer: Exploring purchasing frequencies of fresh fruit and vegetable categories. Journal of Retailing and Consumer Services, 53, 1-9.

ASSAEL, H., ISHIHARA, M. \& KIM, B. J. 2021. Accounting for Causality When Measuring Sales Lift from Television Advertising: Television Campaigns Are Shown To Be More Effective for Lighter Brand Users. Journal of Advertising Research, 61, 3-11.

ATAMAN, M. B., VAN HEERDE, H. J. \& MELA, C. F. 2010. The long-term effect of marketing strategy on brand sales. Journal of Marketing Research, 47, 866-882.

BARNARD, N. \& EHRENBERG, A. 1997. Advertising: Strongly Persuasive or Nudging? Journal of Advertising Research, 37, 21-28.

BELLMAN, S., NENYCZ-THIEL, M., KENNEDY, R., HARTNETT, N. \& VARAN, D. 2019. Best Measures of Attention To Creative Tactics in TV Advertising: When Do Attention-Getting Devices Capture or Reduce Attention? Journal of Advertising Research, 58, 295-311.

BELLMAN, S., NENYCZ-THIEL, M., KENNEDY, R., LARGUINAT, L., MCCOLL, B. \& VARAN, D. 2017. What Makes a Television Commercial Sell? Using Biometrics to Identify Successful Ads. Journal of Advertising Research, 56, 1-14.

BINET, L. \& FIELD, P. 2013. The long and the short of it: Balancing short and longterm marketing strategies, London, Institute of Practitioners in association with Thinkbox.

BINET, L. \& FIELD, P. 2017. Media in Focus: Marketing Effectiveness in the Digital Era. London, UK: Institute of Practitioners in Advertising.

BRONNENBERG, B. J., DUBÉ, J.-P. H. \& GENTZKOW, M. 2012. The evolution of brand preferences: Evidence from consumer migration. American Economic Review, 102, 2472-2508.

CLEMMOW, S. 2012. Four of the Wisest Principles You Will Ever Read. In: LANNON, J. \& BASKIN, M. (eds.) A Master Class in Brand Planning: The Timeless Works of Stephen King. Hoboken, NJ: John Wiley \& Sons.

CONNELL, P. M., BRUCKS, M. \& NIELSEN, J. H. 2014. How Childhood Advertising Exposure Can Create Biased Product Evaluations That Persist into Adulthood. Journal of Consumer Research, 41, 119-134.

DAWES, J. G. 2016. Brand growth in packaged goods markets: Ten cases with common patterns. Journal of Consumer Behaviour, 15, 475-489.

DAWES, J. G. 2018. Price Promotions: examining the buyer mix and subsequent changes in purchase loyalty. Journal of Consumer Marketing, 35, 366-376.

DAWES, J. G., GRAHAM, C. \& TRINH, G. 2020. The long-term erosion of repeatpurchase loyalty. European Journal of Marketing, 1-27.

DAWES, J., GRAHAM, C., TRINH, G. and SHARP, B. 2021. The Unbearable Lightness of Buying. Journal of Marketing Management.Forthcoming 
DUNN, S, Graham, C, Tanusondjaja, A and Nenycz-Thiel, M 2020. Is Category Expansion a Realistic Long-Term Objective for Established Brands? 2020 Academy of Marketing Science World Marketing Congress Brisbane, Australia. Brisbane Australia 14 - 17 Jul 2020

EHRENBERG, A. 1974. Repetitive advertising and the consumer. Journal of Advertising Research, 14, 25-34.

EHRENBERG, A. 1988. Repeat-buying: Facts, theory and applications, London, Oxford University Press.

EHRENBERG, A. \& GOODHARDT, G. 1968. The amount bought by above-average buyers: A communications case-history. Journal of the Market Research Society, 10, 157-171.

EHRENBERG, A., GOODHARDT, G. \& BARWISE, T. P. 1990. Double Jeopardy revisited. Journal of Marketing, 54, 82-91.

EHRENBERG, A. S. C., BARNARD, N., KENNEDY, R. \& BLOOM, H. 2002. Brand advertising as creative publicity. Journal of Advertising Research, 42, 7-18.

EHRENBERG, A. S. C., HAMMOND, K. \& GOODHARDT, G. J. 1994. The after-effects of price-related consumer promotions. Journal of Advertising Research, 34, 11-22.

EHRENBERG, A. S. C., UNCLES, M. D. \& GOODHARDT, G. J. 2004. Understanding brand performance measures: using dirichlet benchmarks. Journal of Business Research, 57, 1307-1325.

FADER, P. S. \& LODISH, L. M. 1990. A cross-category analysis of category structure and promotional activity for grocery products. Journal of Marketing, 54, 52-66.

FULGONI, G. M. 2018. Are You Targeting Too Much? Effective Marketing Strategies for Brands. Journal of Advertising Research, 58, 8-11.

GIJSENBERG, M. J. \& NIJS, V. R. 2019. Advertising spending patterns and competitor impact. International Journal of Research in Marketing, 36, 232-250.

GOODHARDT, G. J. 1966. Constant in duplicated television viewing. Nature, 212, 1616.

GOODHARDT, G. J., EHRENBERG, A. \& CHATFIELD, C. 1984. The Dirichlet: A comprehensive model of buying behaviour. Journal of the Royal Statistical Society, 147, 621-643.

GOODHARDT, G. J., EHRENBERG, A. S. C. \& COLLINS, M. A. 1975. The television audience: Patterns of viewing, Aldershot, United Kingdom, Gower Publishing.

HALLBERG, G. 1995. All Customers are Not Created Equal, New York, John Wiley \& Sons.

IYER, G., SOBERMAN, D. \& VILLAS-BOAS, J. M. 2005. The Targeting of Advertising. Marketing Science, 24, 461-476.

JONES, J. P. 1995. When ads work: New proof that advertising triggers sales, New York, Lexington Books.

JONES, J. P. 2006. When ads work: New proof that advertising triggers sales, New York, M.E. Sharpe, Inc.

KEARNS, Z. 2002. Dirichlet.xls. Palmerston North: Massey University.

KENNEDY, R., DRIESENER, C., GOODHARDT, G., MCDONALD, C. \& WOOD, L. 2008. Using an established framework and Project Apollo data to investigate 
how advertising works. Key Issues Forum of Audience [ME]asurement Symposium. Millennium Broadway Hotel, New York City.

KENNEDY, R. \& HARTNETT, N. 2018. Marketing is scrambled: All evidence-based theorists are invited to breakfast. Australasian Marketing Journal (AMJ), 26, 303-306.

KENNEDY, R., SHARP, B. \& HARTNETT, N. 2017. Advertising. In: SHARP, B. (ed.) Marketing: Theory, Evidence, Practice. Melbourne: Oxford University Press.

LEEFLANG, P. S. H., BIJMOLT, T. H. A., VAN DOORN, J., HANSSENS, D. M., VAN HEERDE, H. J., VERHOEF, P. C. \& WIERINGA, J. E. 2009. Creating lift versus building the base: Current trends in marketing dynamics. International Journal of Research in Marketing, 26, 13-20.

LODISH, L. M., ABRAHAM, M. M., LIVELSBERGER, J., LUBETHKIN, B., RICHARDSON, B. \& STEVENS, M. E. 1995. A Summary of Fifty-Five InMarket Experimental Estimates of the Long-Term Effect of TV Advertising. Marketing Science, 14, G133-G140.

LODISH, L. M. \& MELA, C. F. 2007. If brands are built over years, why are they managed over quarters? Harvard Business Review, 85, 104-112.

MCCARTHY, D. M. \& WINER, R. S. 2019. The Pareto rule in marketing revisited: is it $80 / 20$ or $70 / 20$ ? Marketing Letters, $30,139-150$.

MCDONALD, C. 1996. Advertising Sales Effects. Admap, 39-43.

MONTAGUE, J. 2019. Reframing the awareness funnel and lead nurturing strategies to increase B2B brand awareness and quality lead generation. Journal of Brand Strategy, 8, 160-166.

NENYCZ-THIEL, M., DAWES, J. \& ROMANIUK, J. 2018. Modeling Brand Market Share Change in Emerging Markets. International Marketing Review, 35, 785-805.

RIEBE, E., WRIGHT, M., STERN, P. \& SHARP, B. 2014. How to grow a brand: Retain or acquire customers? Journal of Business Research, 67, 990-997.

RODD, J. 1996. Pareto's law of income distribution, or the 80/20 rule. International Journal of Nonprofit and Voluntary Sector Marketing, 1, 7789.

ROMANIUK, J. 2018. Building Distinctive Brand Assets, South Melbourne, Victoria, Oxford University Press.

ROMANIUK, J., DAWES, J. \& NENYCZ-THIEL, M. 2014. Generalizations regarding the growth and decline of manufacturer and store brands. Journal of Retailing and Consumer Services, 21, 725-734.

ROMANIUK, J. \& WIGHT, S. 2009. The influence of brand usage on responses to advertising awareness measures. International Journal of Market Research, 51, 203-218.

ROMANIUK, J. \& WIGHT, S. 2015. The stability and sales contribution of heavy buying households. Journal of Consumer Behaviour, 14, 13-20.

SANDERS, R. 1987. The Pareto Principle: Its Use and Abuse. Journal of Consumer Marketing, 4, 47-50.

SHARP, B. 2010. How brands grow. In: SHARP, B. (ed.) How Brands Grow. South Melbourne, Australia: Oxford University Press.

SHARP, B., ROMANIUK, J. \& GRAHAM, C. 2019. Marketing's 60/20 Pareto Law. Available at SSRN 3498097. Adelaide, South Australia, Australia: Ehrenberg-Bass Institute. 


\section{LIST OF FIGURES}

Figure 1. Brand and category cumulative penetration growth

Figure 2. Category classification and comparison using sales equation metrics

Figure 3. Summary of targeting factors by category type 


\section{TABLES}

Table 1. Annual category buying and advertising expenditures

\begin{tabular}{lcccccc}
\hline $\begin{array}{c}\text { Category } \\
\text { (by annual size) }\end{array}$ & $\begin{array}{c}\text { Category } \\
\text { Pen. }\end{array}$ & $\begin{array}{c}\text { Category } \\
\text { Buying } \\
\text { Freq. }\end{array}$ & $\begin{array}{c}\text { Leading } \\
\text { Brands }\end{array}$ & $\begin{array}{c}\text { Category } \\
\text { Ad. Spend }\end{array}$ & $\begin{array}{c}\text { Ad. \%o of } \\
\text { Cat. Sales }\end{array}$ & $\begin{array}{c}\text { TV } \\
\text { Spend }\end{array}$ \\
\hline Laundry Detergent & 91 & 6.4 & 5 & 74 & 9 & $>80 \%$ \\
Biscuits \& Mallows & 90 & 19.0 & 5 & 22 & 9 & $>80 \%$ \\
Toothpaste & 88 & 5.8 & 5 & 62 & 7 & $>75 \%$ \\
Skincare & 64 & 5.9 & 5 & 85 & 9 & $>75 \%$ \\
Deodorants & & & & 22 & 8 & $>70 \%$ \\
$\quad$ Women's brands & 55 & 4.4 & 5 & & & \\
Men's brands & 51 & 4.4 & 5 & & & \\
Shampoo & 34 & 3.4 & 5 & 55 & 6 & $>60 \%$ \\
Men's Razors & 30 & 2.0 & 5 & 18 & 5 & $>70 \%$ \\
Ice Cream Sticks & 25 & 3.1 & 4 & 17 & 5 & $>50 \%$ \\
Dog Food & & & & 9 & 8 & $>50 \%$ \\
Wet brands & 24 & 19.1 & 4 & & & \\
Dry brands & 20 & 7.8 & 5 & & & \\
Nappies & 15 & 8.1 & 2 & 10 & 1 & $>60 \%$ \\
Average & & & & & & \\
\hline Data sources: Kantar WorldPanel \& Nielsen Media Research/Mintel & & & & \\
\end{tabular}


Table 2. Cumulative cross-category buying

\begin{tabular}{|c|c|c|c|c|c|c|c|c|c|}
\hline & \multicolumn{3}{|c|}{ Category Sales/100 } & \multicolumn{3}{|c|}{$\begin{array}{l}\text { Cumulative Growth } \\
\text { Penetration (B) }\end{array}$} & \multicolumn{3}{|c|}{$\begin{array}{c}\text { Cumulative Growth } \\
\text { Purchase Frequency (W) }\end{array}$} \\
\hline & Annual & 5 Years & & Annual & 5 Years & $1-5$ & Annual & 5 Years & $1-5$ \\
\hline & & & $x$ fold & & & $\%$ & & & fold \\
\hline Biscuits \& Mallows & 1710 & 8526 & $=5.0$ & 90 & 98 & 9 & 19.0 & 87.0 & 4.6 \\
\hline Laundry Detergent & 585 & 2943 & $=5.0$ & 91 & 99 & 8 & 6.4 & 29.7 & 4.6 \\
\hline Toothpaste & 509 & 2557 & $=5.0$ & 88 & 98 & 11 & 5.8 & 26.2 & 4.5 \\
\hline Wet Dog & 461 & 2308 & $=5.0$ & 24 & 37 & 52 & 19.1 & 62.9 & 3.3 \\
\hline Women's Moisturiser & 377 & 1865 & $=5.0$ & 64 & 88 & 39 & 5.9 & 21.1 & 3.6 \\
\hline Female Deodorant & 244 & 1211 & $=5.0$ & 55 & 78 & 41 & 4.4 & 15.5 & 3.5 \\
\hline Men's Deodorant & 224 & 1117 & $=5.0$ & 51 & 76 & 49 & 4.4 & 14.7 & 3.3 \\
\hline Dry Dog & 156 & 781 & $=5.0$ & 20 & 31 & 55 & 7.8 & 25.2 & 3.2 \\
\hline Nappies & 122 & 618 & $=5.1$ & 15 & 29 & 93 & 8.1 & 21.3 & 2.6 \\
\hline Shampoo & 117 & 582 & $=5.0$ & 34 & 53 & 55 & 3.4 & 10.9 & 3.2 \\
\hline Choc Coated Ice Cream & 78 & 359 & $=4.6$ & 25 & 57 & 128 & 3.1 & 6.3 & 2.0 \\
\hline Men's Razors & 60 & 305 & $=5.1$ & 30 & 61 & 103 & 2.0 & 5.0 & 2.5 \\
\hline Average & 387 & 1931 & $=\quad 5.0$ & 49 & 67 & 54 & 7 & 27 & 3.4 \\
\hline
\end{tabular}

Table 3. Cumulative Buying: Men's Deodorants. Quarter, Annual and 5 Years

\begin{tabular}{|c|c|c|c|c|c|c|c|c|c|c|}
\hline & $\begin{array}{c}\text { Market } \\
\text { Share } \\
\% \\
\end{array}$ & $\begin{array}{c}\text { Avg.Q } \\
b \\
\% \\
\end{array}$ & $\begin{array}{l}\text { irter } \\
\text { w }\end{array}$ & $\begin{array}{c}\text { An } \\
b \\
\%\end{array}$ & $w$ & $\begin{array}{c}5 \mathrm{Ye} \\
b \\
\% \\
\end{array}$ & irs & Year & $\begin{array}{l}\text { les } / 10 \\
5 \mathrm{Yr}\end{array}$ & xFold \\
\hline Category & 100 & 27 & 2.1 & 51 & 4.4 & 76 & 14.7 & 224 & 1117 & 5.0 \\
\hline Lynx & 28 & 8 & 1.9 & 19 & 3.2 & 43 & 7.4 & 63 & 315 & 5.0 \\
\hline Right Guard & 14 & 5 & 1.6 & 12 & 2.5 & 28 & 5.3 & 30 & 151 & 5.0 \\
\hline Sure & 13 & 5 & 1.5 & 12 & 2.4 & 30 & 4.9 & 29 & 145 & 5.0 \\
\hline Adidas & 7 & 2 & 1.5 & 7 & 2.0 & 23 & 3.4 & 15 & 76 & 5.0 \\
\hline Gillette & 5 & 2 & 1.4 & 6 & 1.8 & 18 & 3.0 & 11 & 55 & 5.0 \\
\hline Average & 13 & 4 & 1.6 & 11 & 2.4 & 28 & 4.8 & 30 & 148 & 5.0 \\
\hline
\end{tabular}


Table 4. Patterns of cumulative brand performance by market share $(n=46)$

\begin{tabular}{|c|c|c|c|c|c|c|c|}
\hline & $\begin{array}{r}\text { Market } \\
\text { Share } \\
\% \\
\end{array}$ & \multicolumn{2}{|c|}{$\begin{array}{l}\text { Quarter } \\
\begin{array}{c}b \\
\%\end{array} \\
\end{array}$} & \multicolumn{2}{|c|}{$\begin{array}{l}\text { Annual } \\
b \\
\%\end{array}$} & $\begin{array}{r}\text { Five } \\
b \\
\% \\
\end{array}$ & ars \\
\hline Category Average & $\begin{array}{r}\% \\
100\end{array}$ & 31 & 2.9 & 49 & 7.4 & 67 & 27.1 \\
\hline Ave. Market Leader & 23 & 10 & 1.9 & 21 & 3.4 & 41 & 8.3 \\
\hline Ave. Follower Brand & 13 & 6 & 1.9 & 13 & 3.2 & 29 & 7.0 \\
\hline Ave. Brand 3 & 9 & 5 & 1.6 & 12 & 2.7 & 27 & 5.6 \\
\hline Ave. Brand 4 & 6 & 4 & 1.5 & 9 & 2.3 & 24 & 4.5 \\
\hline Ave. Brand 5 & 4 & 4 & 1.5 & 8 & 2.4 & 20 & 4.3 \\
\hline Average & 11 & 6 & 1.7 & 13 & 2.8 & 28 & 5.9 \\
\hline
\end{tabular}

Table 5. Observed super-light buying in cumulative performance $(n=46)$

\begin{tabular}{|c|c|c|c|c|c|c|c|}
\hline & \multicolumn{5}{|c|}{$\%$ buying $n$ times over 5 years } & \multirow{2}{*}{$\begin{array}{c}\text { Total } \\
\text { Super-lights }\end{array}$} & \multirow{2}{*}{$\begin{array}{c}\text { Contribution } \\
\text { to Sales }\end{array}$} \\
\hline & 1 & 2 & 3 & 4 & 5 & & \\
\hline & $\%$ & $\%$ & $\%$ & $\%$ & $\%$ & $\%$ & $\%$ \\
\hline Ave. Market Leader & 31 & 15 & 10 & 7 & 5 & 68 & 29 \\
\hline Ave. Follower Brand & 38 & 16 & 10 & 6 & 5 & 75 & 35 \\
\hline Ave. Brand 3 & 41 & 17 & 9 & 6 & 4 & 77 & 38 \\
\hline Ave. Brand 4 & 47 & 18 & 9 & 6 & 4 & 83 & 51 \\
\hline Ave. Brand 5 & 49 & 16 & 9 & 6 & 4 & 84 & 52 \\
\hline Average & 41 & 16 & 9 & 6 & 4 & 77 & 41 \\
\hline
\end{tabular}


Table 6. Cumulative projections to observed performance

\begin{tabular}{|c|c|c|c|c|c|c|c|c|c|c|c|c|c|c|c|}
\hline & & & & nnual & Perform & ance $\mathrm{M}$ & easures & & Cumul & ive 5 & Year $\mathrm{P}$ & erforma & ce Mea & sures & \\
\hline & & $\begin{array}{l}\text { Market } \\
\text { Share }\end{array}$ & $\begin{array}{r}\text { Penetr } \\
\%\end{array}$ & & $\begin{array}{r}\text { Purchas } \\
\text { Buy }\end{array}$ & $\begin{array}{l}\text { es per } \\
\text { er }\end{array}$ & $\begin{array}{r}1 \times \mathrm{Bu} \\
\%\end{array}$ & & $\begin{array}{r}\text { Penetr } \\
\%\end{array}$ & & $\begin{array}{r}\text { Purchas } \\
\text { Buy }\end{array}$ & $\begin{array}{l}\text { es per } \\
\text { yer }\end{array}$ & $\begin{array}{r}1 \times \mathrm{Bu} \\
\%\end{array}$ & & $\begin{array}{c}\text { Sales. } \\
/ 100 .\end{array}$ \\
\hline & & & $\mathrm{O}$ & $\mathbf{T}$ & $\mathrm{O}$ & $\mathbf{T}$ & $\mathrm{O}$ & $\mathbf{T}$ & $\mathrm{O}$ & $\mathbf{T}$ & $\mathrm{O}$ & $\mathbf{T}$ & $\mathrm{O}$ & $\mathbf{T}$ & \\
\hline $\mathbf{H i} / \mathbf{H i}$ & Av.Leader & 23 & 47 & 47 & 3.4 & 3.5 & 38 & 36 & 77 & 68 & 10.4 & 11.8 & 16 & 14 & 5 \\
\hline & Av.Follower & 13 & 29 & 34 & 3.7 & 3.1 & 42 & 41 & 57 & 54 & 9.6 & 9.9 & 24 & 18 & 5 \\
\hline & Av. Brand 3 & 9 & 23 & 25 & 3.1 & 2.9 & 44 & 44 & 47 & 41 & 7.7 & 8.7 & 28 & 20 & 5 \\
\hline & Av. Brand 4 & 6 & 21 & 18 & 2.3 & 2.7 & 55 & 46 & 46 & 30 & 5.2 & 7.9 & 33 & 22 & 5 \\
\hline & Av. Brand 5 & 5 & 17 & 15 & 2.4 & 2.7 & 53 & 47 & 39 & 26 & 5.2 & 7.8 & 37 & 23 & 5 \\
\hline & Average & 11 & 27 & 28 & 3.0 & 3.0 & 46 & 43 & 53 & 44 & 7.6 & 9.2 & 28 & 20 & 5 \\
\hline & $(\mathrm{O}-\mathrm{T}) / \mathrm{O}$ & & & $-1 \%$ & & $1 \%$ & & $8 \%$ & & $7 \%$ & & $-21 \%$ & & $30 \%$ & $0 \%$ \\
\hline Hi/Lo & Av.Leader & 17 & 16 & 17 & 2 & 2 & 58 & 55 & 38 & 33 & 5.2 & 5.8 & 40 & 33 & 5 \\
\hline & Av.Follower & 10 & 10 & 11 & 2 & 2 & 61 & 58 & 26 & 23 & 4.4 & 5.0 & 45 & 36 & 5 \\
\hline & Av. Brand 3 & 9 & 10 & 10 & 2 & 2 & 62 & 58 & 28 & 21 & 4.0 & 4.9 & 46 & 36 & 5 \\
\hline & Av. Brand 4 & 6 & 7 & 6 & 2 & 2 & 70 & 60 & 21 & 13 & 2.9 & 4.5 & 54 & 38 & 5 \\
\hline & Av. Brand 5 & 5 & 5 & 5 & 2 & 2 & 69 & 61 & 15 & 10 & 3.2 & 4.4 & 56 & 39 & 5 \\
\hline & Average & 10 & 10 & 10 & 2.1 & 2.1 & 64 & 58 & 26 & 20 & 4.0 & 4.9 & 48 & 36 & 5 \\
\hline & $(\mathrm{O}-\mathrm{T}) / \mathrm{O}$ & & & $-2 \%$ & & $0 \%$ & & $8 \%$ & & $1 \%$ & & $-25 \%$ & & $24 \%$ & $3 \%$ \\
\hline Lo/HI & Av.Leader & 26 & 8 & 9 & 5.7 & 5.6 & 33 & 37 & 18 & 15 & 13.2 & 16.7 & 25 & 24 & 5 \\
\hline & Av.Follower & 16 & 6 & 6 & 4.9 & 5.1 & 38 & 39 & 15 & 11 & 10.7 & 14.7 & 27 & 26 & 5 \\
\hline & Av. Brand 3 & 7 & 5 & 4 & 4.3 & 5.4 & 41 & 40 & 12 & 7 & 8.8 & 15.4 & 33 & 26 & 5 \\
\hline & Av. Brand 4 & 4 & 3 & 3 & 4.4 & 5.2 & 42 & 41 & 8 & 4 & 8.7 & 14.6 & 36 & 26 & 5 \\
\hline & Av. Brand 5 & 3 & 1 & 1 & 5.3 & 4.0 & 46 & 45 & 3 & 2 & 8.5 & 11.2 & 46 & 29 & 5 \\
\hline & Average & 11 & 5 & 4 & 4.9 & 5.0 & 40 & 40 & 11 & 8 & 10.0 & 14.5 & 33 & 26 & 5 \\
\hline & $(\mathrm{O}-\mathrm{T}) / \mathrm{O}$ & & & $6 \%$ & & $-2 \%$ & & $-1 \%$ & & $0 \%$ & & $-45 \%$ & & $22 \%$ & $-1 \%$ \\
\hline Lo/Lo & Av.Leader & 30 & 10 & 11 & 2.0 & 1.9 & 64 & 61 & 27 & 22 & 3.5 & 4.3 & 45 & 38 & 5 \\
\hline & Av.Follower & 14 & 5 & 5 & 1.8 & 1.8 & 71 & 63 & 16 & 12 & 2.7 & 3.9 & 55 & 42 & 5 \\
\hline & Av. Brand 3 & 8 & 3 & 3 & 1.8 & 1.8 & 72 & 65 & 10 & 8 & 2.7 & 3.8 & 59 & 43 & 5 \\
\hline & Av. Brand 4 & 2 & 1 & 1 & 1.4 & 1.7 & 72 & 66 & 6 & 2 & 1.8 & 3.6 & 72 & 45 & 5 \\
\hline & Average & 13 & 5 & 5 & 1.7 & 1.8 & 70 & 64 & 15 & 11 & 2.7 & 3.9 & 58 & 42 & 5 \\
\hline & $(\mathrm{O}-\mathrm{T}) / \mathrm{O}$ & & & $0 \%$ & & $-4 \%$ & & $9 \%$ & & $6 \%$ & & $-47 \%$ & & $28 \%$ & $0 \%$ \\
\hline
\end{tabular}


Table 7. Research Questions and Summary Answers

\begin{tabular}{|c|c|}
\hline Research Question & Summary Findings \\
\hline $\begin{array}{l}\text { RQ1. How does } \\
\text { cumulative category } \\
\text { buying vary over } \\
\text { time (e.g. between } \\
\text { one and five years)? }\end{array}$ & $\begin{array}{l}\text { In stationary markets, cumulative category penetration takes a } \\
\text { number of forms. Large categories can saturate after a year, while } \\
\text { others continue to grow substantially over the long term. The target } \\
\text { market for brands is then far larger than that seen in annual buying } \\
\text { data. Some categories have a natural ceiling (well below } 100 \% \text { ). } \\
\text { Given many in the population will never buy them, these have a } \\
\text { restricted target market. Such markets can also take years to } \\
\text { saturate. Since cumulative sales in stationary markets are linear, } \\
\text { the rate of category penetration growth is reflected in the growth } \\
\text { rate of average purchase frequency. This has implications for long- } \\
\text { run brand planning and the advertising objectives required to } \\
\text { maintain or grow sales. Category penetration and rate of buying } \\
\text { appear to be a useful basis to define four distinct market types. }\end{array}$ \\
\hline $\begin{array}{l}\text { RQ2 How does } \\
\text { cumulative brand } \\
\text { buying vary over } \\
\text { time and conditions? }\end{array}$ & $\begin{array}{l}\text { Cumulative brand buying metrics mostly grow systematically over } \\
\text { five years, consistent with the sales equation. Where conditions are } \\
\text { stationary, five-year cumulative sales are fivefold annual sales but } \\
\text { brands get there in different combinations of penetration and } \\
\text { purchase frequency growth depending on a range of conditions } \\
\text { (market type, market share and dynamism - see RQ2a-c). }\end{array}$ \\
\hline $\begin{array}{l}\text { RQ2a How does } \\
\text { cumulative brand } \\
\text { buying vary by } \\
\text { market type? }\end{array}$ & $\begin{array}{l}\text { Brand buying reflects category buying with brand penetration } \\
\text { growing dramatically in Low Penetration / Low Purchase } \\
\text { Frequency markets where Purchase Frequency is restricted. In } \\
\text { comparison, in High Penetration / High Purchase Frequency } \\
\text { markets, brand penetration grows but only just doubles (2x) while } \\
\text { Purchase Frequency grows almost fivefold (5x) in five years. }\end{array}$ \\
\hline $\begin{array}{l}\text { RQ2b How does } \\
\text { cumulative brand } \\
\text { buying vary by brand } \\
\text { share? }\end{array}$ & $\begin{array}{l}\text { Across categories, smaller stable brands rely more on penetration } \\
\text { growth and less on Purchase Frequency growth. In cumulative data } \\
\text { over time, DJ is more pronounced. }\end{array}$ \\
\hline $\begin{array}{l}\text { RQ3 Are NBD- } \\
\text { Dirichlet benchmarks } \\
\text { of cumulative buying } \\
\text { robust for longer } \\
\text { term advertising and } \\
\text { media planning? }\end{array}$ & $\begin{array}{l}\text { The NBD-Dirichlet projections of cumulative brand performance } \\
\text { are not entirely accurate over five years. There is a close match for } \\
\text { total sales (theoretical compared to observed) but a systematic bias } \\
\text { in fit. Specifically, penetration is under predicted and average } \\
\text { purchase frequency is over predicted. } \\
\text { The bias is systematically more extreme for smaller brands than } \\
\text { larger. } \\
\text { Low Penetration / High Purchase Frequency and Low Penetration / } \\
\text { Low Purchase Frequency have a better fit than High Penetration / } \\
\text { High Purchase Frequency and High Penetration / Low Purchase } \\
\text { Frequency categories. }\end{array}$ \\
\hline
\end{tabular}


From a targeting perspective, the confirmation of the importance of the Super Light buyers and the excess of one-time buyers over five years is critical.

The bias in one time buying replicates the discrepancy in NBD fittings referred to in Goodhardt et al.(1984, p.627) - a 15\% shortfall in one quarter for the toothpaste category. We demonstrate how much further the model underpredicts one-time brand buyers with time; almost twice that for an average brand in five years of cumulative purchasing. 


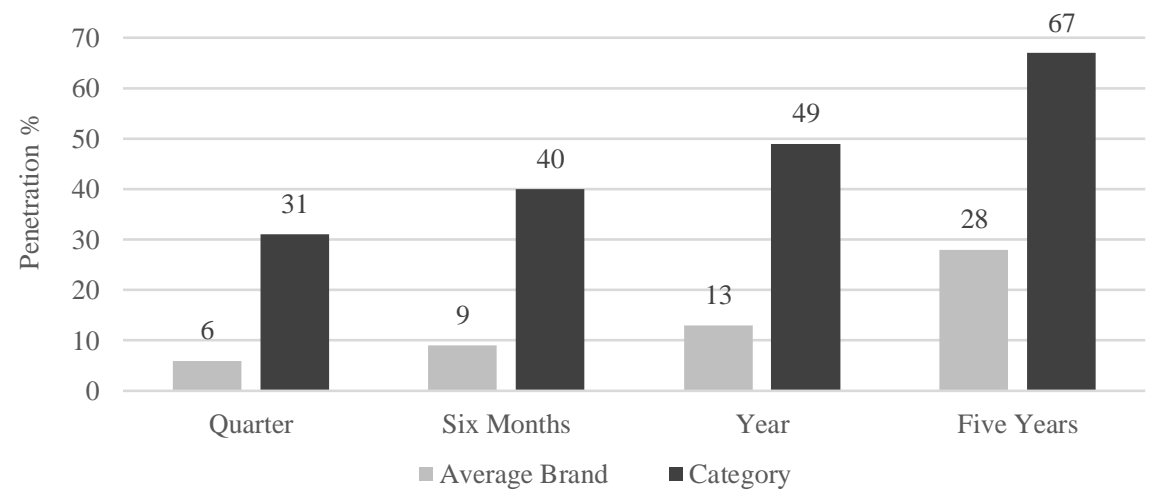

Figure 1. Brand and category cumulative penetration growth. Mean penetration values for 12 categories and 46 brands Cumulative category penetration doubles between a quarter and five years. Brand penetrations double from a quarter to a year, and again in five years. 


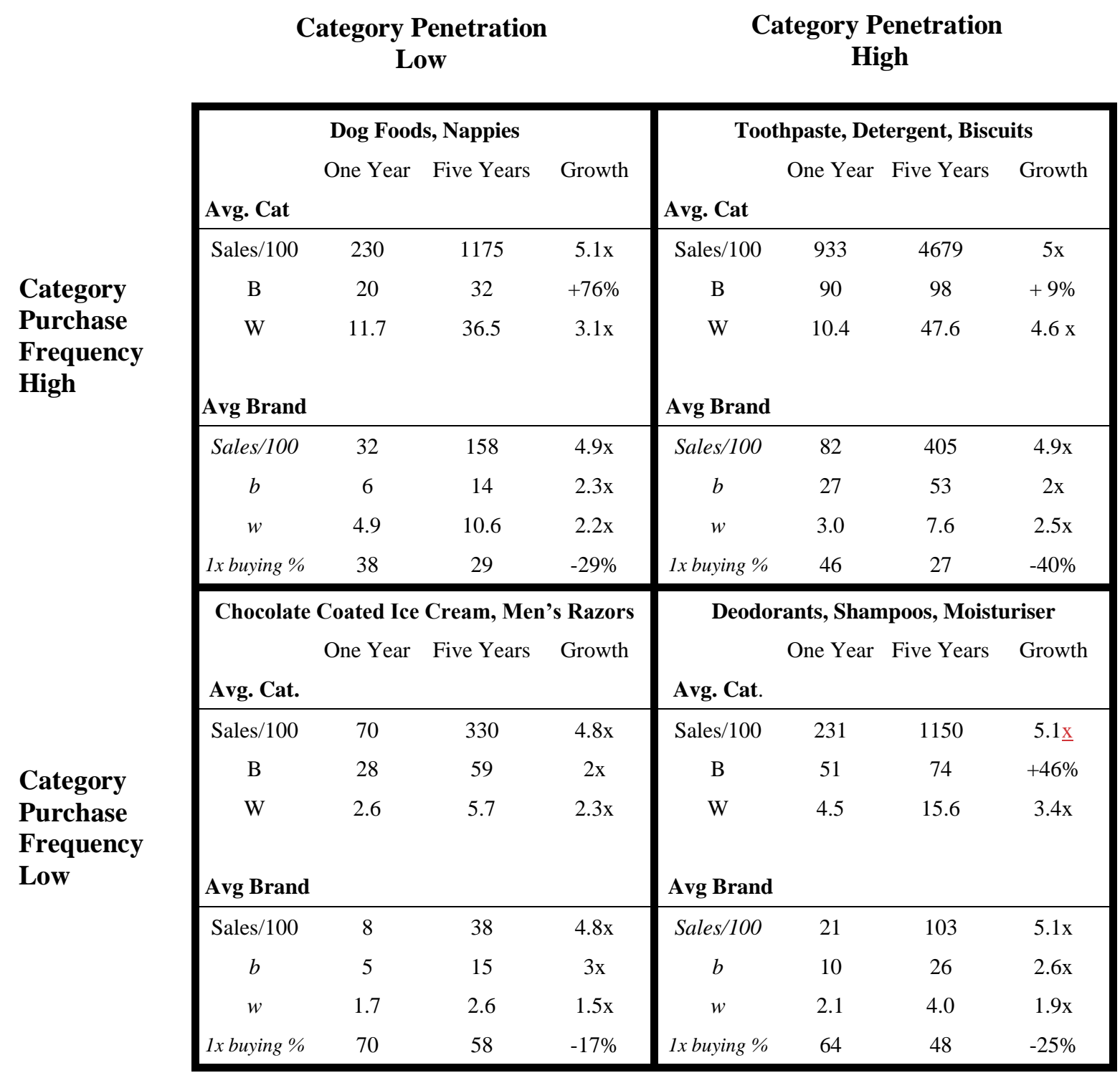

Figure 2. Category classification and comparison using sales equation metrics 


\begin{tabular}{|c|c|c|}
\hline & $\begin{array}{c}\text { Category Penetration } \\
\text { Low }\end{array}$ & $\begin{array}{c}\text { Category Penetration } \\
\text { High }\end{array}$ \\
\hline $\begin{array}{c}\text { Category } \\
\text { Purchase } \\
\text { Frequency } \\
\text { High }\end{array}$ & $\begin{array}{l}\text { Category Penetration is limited. Even in the long } \\
\text { term these categories maintain a long-term base of } \\
\text { non-buyers }(\sim 70 \%) \text {. } \\
\text { While there is a ceiling on the core target market, } \\
\text { new category buyers do come in over the longer } \\
\text { term and should not be ignored. Some broader } \\
\text { brand building like establishing links to the } \\
\text { category may be useful, especially for the biggest } \\
\text { brands. } \\
\text { Reaching and nudging new category buyers (e.g. } \\
\text { new parents or dog owners) is likely to be key to } \\
\text { communications strategy. There may be a role in } \\
\text { educating new buyers as part of building relevant } \\
\text { memory structures to make it easy for these people } \\
\text { to buy the brand. }\end{array}$ & $\begin{array}{l}\text { Limited cumulative category penetration growth is } \\
\text { expected in these categories. } \\
\text { Most buyers are already in the market so advertising } \\
\text { must mostly nudge brand consideration and refresh } \\
\text { relevant brand memories (e.g. links to category } \\
\text { entry points). } \\
\text { Brands rely on repeat buying and nudging brand } \\
\text { sales from within shoppers' repertoires. }\end{array}$ \\
\hline $\begin{array}{c}\text { Category } \\
\text { Purchase } \\
\text { Frequency } \\
\text { Low }\end{array}$ & $\begin{array}{l}\text { These categories double in size, with } \\
\text { Purchase Frequency increases being the smallest } \\
\text { across the quadrants (only doubles). } \\
\text { Advertising must nudge category and brand buying. } \\
\text { Given the very high rates of light / infrequent } \\
\text { buying, consistency of branding is vital over time. }\end{array}$ & $\begin{array}{l}\text { Some category growth is experienced with these } \\
\text { categories so ongoing reach matters. } \\
\text { Many buyers are already in the market so they have } \\
\text { some knowledge of the category. Ads must nudge } \\
\text { the brand while continuing to refresh relevant } \\
\text { memory structures to nudge the category. } \\
\text { With some "new" category buyers it is vital the } \\
\text { brand is easy to notice and buy. }\end{array}$ \\
\hline
\end{tabular}

\section{Figure 3. Summary of Targeting factors by Category type}

